\begin{tabular}{c} 
Volume and Issues Obtainable at Center for Sustainability Research and Consultancy \\
Journal of Accounting and Finance in Emerging Economies \\
ISSN: 2518-0318 ISSN (E) 2518-8488 \\
Volume 6: Issue 2 June 2020 \\
CSRC \\
Journal homepage: $\underline{\text { www.publishing.globalcsrc.org/jafee }}$ \\
\hline
\end{tabular}

\title{
Corporate Governance and Stock Price Informativeness: Evidence from an Emerging Market
}

\author{
${ }^{1}$ Muhammad Shahid Rasheed, ${ }^{2}$ Shahzad Kouser
}

${ }^{1}$ Department of Management Sciences, COMSATS University, Islamabad, Pakistan, mshahid351@ yahoo.com ${ }^{2}$ Department of Economics, COMSATS University, Islamabad, Pakistan, drskouser@ comsats.edu.pk

ARTICLE DETAILS

History

Revised format: May 2020

Available Online: June 2020

\section{Keywords}

Corporate Governance, Synchronicity, Controlling

Shareholders, Institutional

Investors, Family Ownership

JEL Classification

G34, G23, G11, G32, G14

\begin{abstract}
Emerging markets usually have weaker legal and governance environment. The weaker enforcement of investor protection laws leads to a poor information environment. Using data of all the listed non-financial firms from Pakistan stock exchange (PSX), we document the relationship between corporate governance variables and stock price informativeness. The results from two-stage least squares (2SLS) reveal that controlling shareholders in the form of block holding plays an effective role in improving informativeness. Due to the presence of these block ownership, the institutional investors remain largely short term investors and act passively. This behavior of institutional investors encourages managers to extract more cash flows leading to higher synchronicity. These findings suggest market regulators develop such a corporate governance mechanism that not only ensures investor protection but also advise firms to reduce information asymmetry by better disclosure and transparency. More specifically, in the Pakistani context, traditional corporate governance mechanisms through board room regulations may not improve informativeness, and regulators need to regulate the ownership regulations, including family ownership and controlling shareholders.
\end{abstract}

(C) 2020 The authors, under a Creative Commons AttributionNonCommercial 4.0

Corresponding author's email address: mshahid351@yahoo.com

Recommended citation: Rasheed, M. S. and Kouser, S. (2020). Corporate Governance and Stock Price Informativeness: Evidence from an Emerging Market. Journal of Accounting and Finance in Emerging Economies, 6(2), 593-605

\section{Introduction}

For many years, the role of effective corporate governance in reducing information asymmetry between firms' managers and its shareholders remained a major focus among researchers and policymakers. Audit failures and corporate scandals like Enron and Worldcom, have increased focus on enhancing information disclosure and transparency through effective corporate governance (Chen et al., 2017). Stock prices reflect information about firm fundamentals and markets as well. The more a firm's stock price movement is based on its fundamentals, the better its price informativeness. Roll (1988), in his seminal study, finds "the extent to which stock prices move together depends on the relative amount of firm-specific and market-level information impounded in stock prices." Emerging 
markets usually have weaker corporate governance and hence have poor information environment (Morck et al., 2000). Extant literature establishes that stock prices depict more firm-specific information in markets with better property rights protection, investor protection, and a better governance environment (Alves et al., 2010; Dasgupta et al., 2010; Jin \& Myers, 2006). These mechanisms are either weak or absent in emerging markets. In the absence of these mechanisms, the information environment and disclosure culture remain poor in such markets (Balasubramanian et al., 2010). This poor information environment remains a fundamental problem in emerging markets. Poor information environment has severe consequences for market participants, especially for emerging markets. Information asymmetry causes stock price movements that may be unrelated to firm fundamentals, thus results in over or undervaluation (Roll, 1988). Investors are exposed to greater risk ((Campbell et al., 2001), have lower investment efficiency (Chen et al., 2006) due the presence of information asymmetry in the market.

Pakistan is one of the fast-growing emerging financial markets in the world (Arshad et al., 2016). Mostly, the firms in emerging markets are usually owned, managed and also controlled by the insiders. The biggest shareholder is often the board chairperson, which is one of the reasons for ineffective traditional governance mechanisms in these markets (Rehman et al., 2012). In the case of Pakistan, it is being observed that most firms are controlled and managed by families which may lead to the expropriation of minority shareholders (Sheikh et al., 2018). Earlier studies by Durnev and Kim (2005), and Love and Klapper (2002) proposed that corporate governance practices matter the most in countries having weaker investor protection and governance system.

Less informative markets provide an opportunity to informed traders to earn abnormal returns (Budsaratragoon et al., 2014). As indicated by De Long et al. (1990), stock prices experience higher market-wide stock price variations unrelated to firm fundamentals due to increased market-wide noise trader risk resulted from reduced informed trading. Corporate governance can play an important role in decreasing this information asymmetry and improving transparency (Budsaratragoon et al., 2014). Different corporate governance aspects improve the information environment. For instance, Boubaker et al. (2014) found controlling shareholders decreases informativeness, Gul et al. (2010) observed that concentrated ownership increase synchronicity while foreign shareholding reduces synchronicity. Feng et al. (2016) found the separation of control and ownership rights creates agency issues among controlling and minority shareholders reducing informativeness. Kun et al. (2017) found that the presence of institutional investors increase informativeness because they have an information advantage over individual investors. An and Zhang (2013) find long term investments of institutional investors increased informativeness, while the short term investment behavior causes a reduction in informativeness. Luo et al. (2014) document a positive relationship between institutional shareholding and informativeness.

On the other hand, DeLisle et al. (2017) proposed a rise in passive institutional investors for the last couple of decades, which have negative implications for market efficiency. Kim and Zhang (2016) found independent directors reduce information asymmetry and solve agency problems. The literature documents a strong link between corporate governance and firm's price informativeness; however, what aspects and elements of corporate governance contributing towards reducing information asymmetry remain inconclusive.

Pakistan is an emerging market and has unique characteristics. In Pakistan, most firms are controlled and managed by families which may lead to the expropriation of minority shareholders (Sheikh et al., 2018). Moreover, Pakistan's legal and political system is weaker, and the overall governance environment is poor (Rehman et al., 2012). This study investigates how these unique settings of corporate governance influence the firms' information environment.

To measure stock price informativeness, the present study uses $\mathrm{R}^{2}$ from a modified model using contemporaneous returns. Further, to overcome the bounded properties of $\mathrm{R}^{2}$, we use logarithmic transformation (Gul et al., 2010; Piotroski \& Roulstone, 2004). To address issues like endogeneity, the study also uses fixed effects estimators.

This study has useful insights for the security analysts, investment bankers, and auditors who continuously monitor companies as the quality and size of information add or destroy the long term firm's value. This study is also potentially informative for regulators and policymakers as it defines the role of corporate governance in improving the information environment, which is an important tool of investor protection. Further, we document the relationship 
between corporate governance variables and firm information environment in unique settings of emerging markets. The earlier literature on this subject is limited to developed markets and has limited implications for emerging economies like Pakistan.

\section{Literature Review}

Financial economists argue a strong association between a firm's stock performance and the quality of the firm's directors. Further research finds firms with a large portion of outside directors serving one more other boards found mediocre future performance and lowers the value of firms stock (Fich \& Shivdasani, 2006). Fairchild and Li (2005) found no relationship between the categories of directors whether to hire outside directors of the firm or director of acquired firm and stock market performance of those firms. We expect board size and the presence of independent directors reduce synchronicity.

Corporate governance features have different possible effects on stock price synchronicity. Boubaker et al. (2014) find stock price synchronicity increases through increased controlling by the shareholders. Gul et al. (2010) investigated the impact of concentrated ownership on stock price synchronicity. Synchronicity is higher in circumstances when a large number of shareholders related to the government. This paper also examined the inverse relation of synchronicity with foreign ownership and auditor quality. Our study expects an inverse relationship of concentrated ownership with stock price informativeness.

Ding et al. (2017), using data for the Chinese listed firms, found that analyst coverage restricts managers from withholding firm-specific information, thus improve the information environment. They also observed improved stock price informativeness in the presence of developed financial intermediaries and less government expropriation but the reduced role of analyst coverage in informativeness. Apart from corporate boards, regional institutions also play an important role in shaping corporate policy.

Institutional investors have the power to change the firm and engage their recourses to enhance the firm's corporate governance. Institutional characteristics play an important role in increasing stock price informativeness. In a unique province-level institutional characteristic, Hasan et al. (2014) found that developed legal and political institutions ensured more informative stock prices. Political pluralism, better property rights and rules of law reduce stock price synchronicity.

The investment behaviour of institutional investors also contributes towards firm's informativeness. From one perspective, short term institutional investors focus on short term gains having high portfolio turnover. In such cases, they don't have strong incentives to collect firm-specific information, thus have no role in improving the information environment (An \& Zhang, 2013). Moreover, this short-term behavior encourages herd behavior in the market by buying and selling on trends which increases the stock price synchronicity (Jin et al., 2016). Then again, when the institutional investors maintain larger stakes for a long time, they have larger incentives to closely monitor their investment portfolio. Shleifer and Vishny (1987) suggested that because the size, institutional investors have the power to monitors and promote the best practices of corporate governance.

Stock price synchronicity is negatively related to the firm's ownership by committed institutional investors. The committed institutional investors have a strong benefit of monitoring because of their heavy investments (An \& Zhang, 2013). Their findings suggest institutional investor's monitoring limits the cash extraction of managers, which helps to reduce firm-specific risk, and due to this R-squared is lower. Sometimes, these institutional investors took a large position having representation on the firm's board. Therefore, long term institutional investors improve firm information environment and reduce stock price synchronicity (An \& Zhang, 2013).

Kun et al. (2017) found institutional shareholders help in reducing synchronicity and improving information efficiency. The improvement in information efficiency is mainly due to long term investments by institutional investors. Therefore, policymakers and regulators should encourage long term investment that results in improved resource allocation in the stock market. DeLisle et al. (2017) proposed a rise in passive institutional investors since the last couple of decades. This rise in institutional holding has negative implications for market efficiency. Passive 
institutional usually do not trade around firm-specific news and thus result in reducing firm-specific price informativeness.

Luo et al. (2014) used intraday data from the Japanese market to investigate the role of institutional investors in increasing price informativeness. They proposed that institutional investors have better access to information than retail investors. The presence of institutional investors improve firm's information environment. Moreover, this positive relationship is stronger among firms having foreign institutional investors.

Brockman and Yan (2009) examined the impact of the block holder on the firm's information. Previously studies show the cost to obtain private information effects on stock price efficiency. Block holders have an advantage over disperse shareholders as they can acquire private information with minimum cost. Ye et al. (2018) used synchronicity as a measure of informativeness using a large sample from 1984-2014 in US market. They find improved informativeness for firms that are strategically deviated from the relative industry. This improvement is more pronounced in a firm having more block holders. These results are robust to change in the measure of informativeness and other controls.

\section{Data and Methodology}

The study uses data from all the listed non-financial firms in Pakistan stock exchange (formerly Karachi stock exchange) for the period of 2009 to 2017. We exclude all the financial firms due to the highly regulated environment and different contextual settings, especially separate corporate governance guidelines. Further, PSX observed a floor in prices in 2008, which resulted in limited trading activities. The prices could move upward within a prescribed range but could not move below the level from the day of the imposition of the floor. This limited trading makes difficult price discovery phenomena, thus disturbing the market efficiency ${ }^{1}$, so this study also explores the information environment after the imposition of the floor. The final sample contains an unbalanced panel of 264 non-financial firms from 12 broad sectors listed in PSX having 2335 firm-year observations. To include in a sample, a firm essentially has at least three years of continuous data during the sample period, and firms listed after 2016 are excluded based on this criterion. Following Gul et al. (2010), we use $\mathrm{R}^{2}$ from following the market model to measure the stock price synchronicity.

$$
R_{i t}=\alpha_{i}+\beta_{1} R_{m t}+\varepsilon_{i t}
$$

Where $R_{i t}$ is the return of firm $i$ at time $t, R_{m t}$ is the market return at $t, \alpha_{i}$, and $\beta_{i t}$ are estimated parameters and $\varepsilon_{i t}$ represents error term. This study uses the logistic transformation of $\mathrm{R}^{2}$ obtained from the above equation (1) to overcome the restricted nature of $\mathrm{R}^{2}$ within 0 and 1 (Yeung \& Lento, 2018).

$$
S Y N C H_{i t}=\ln \left(\frac{R_{i t}^{2}}{1-R_{i t}^{2}}\right)
$$

This study uses individual measures of corporate governance which theoretically play an important role in the flow of information.

SYNCH $_{i t}=\alpha_{i t}+\beta_{1} C E O_{i t}+\beta_{2} B S_{i t}+\beta_{3}$ BCOM $_{i t}+\beta_{4} I_{\text {INSTOWN }}+\beta_{5}$ BLOCK $_{i t}+\beta_{6} F A M I L Y+\beta_{7} F S I Z E_{i t}+$ $\beta_{8} L E V_{i t}+\beta_{9} M B_{i t}+\beta_{10} A G E_{i t}+\beta_{11} R O A_{i t}+\beta_{t} I N D U S T R Y+\beta_{t} Y E A R+\varepsilon_{i t}$

Where $S Y N C H$ is firm-level price synchronicity which is measured by $\mathrm{R}^{2}$ of market model regression using equation $1, C E O$ shows a dummy variable equal to one if the CEO is the same as the chairman, $B S$ shows board size, $B C O M$ shows board composition, INSTOWN represents institutional investors, BLOCK represents block shareholders.

\section{Results and Discussion 4.1. Descriptive Statistics}

\footnotetext{
${ }^{1}$ Report of the Committee: Study of the Pakistan Stock Market Crisis of 2008, (June 05, 2015) 
Table 1 shows the descriptive statistics for all the variables used in the model. The average value of $\mathrm{R}^{2}$ for the sample is .08 which is consistent with the Roll (1969) who argued that lower $\mathrm{R}^{2}$ is associated with stock prices reflect a large amount of firm-specific variations as compared to market variations. Similar to Chen et al. (2007) and An and Zhang (2013), we also observe a lower value of synchronicity (SYNCH) having a mean value of -3.87. Board Size (BSIZE) has a mean value of 8 with Board Independence (BCOM) mean of $62.15 \%$. The institutional shareholding (INSTOWN) stands at $15.9 \%$ showing lesser presence of institutional shareholding. The controlling shareholder (BLOCK) shows a mean value of 2.39 showing the presence of large controlling shareholders among our sample firms. The control variables also show some distinct patterns. Family ownership (FAMILY) has a mean value of .76 showing presence of family-owned firms in Pakistan. Firm size (FSIZE) has a mean value of 8.43, Leverage (LEV) has a mean value of .36 showing a moderate level of firms financed by debt. Market to book (MB) shows a mean value of 1.47, firm age (AGE) has a mean value of 38 years, and profitability (ROA) has a mean of 3.8\%.

Table 1: Descriptive Statistics

\begin{tabular}{llllll}
\hline Variable & Obs & Mean & Std. Dev. & Min & Max \\
\hline R $^{2}$ & 2335 & 0.08 & 0.108 & .00000035 & 0.6466 \\
SYNCH & 2335 & -3.87 & 2.42 & -11.57 & -0.17 \\
CEO & 2335 & 0.18 & 0.38 & 0 & 1 \\
BSIZE & 2335 & 8.00 & 1.54 & 5 & 90 \\
BCOM & 2335 & 62.15 & 17.27 & 28.57 & .92 \\
INSTOWN & 2335 & .159 & 0.19 & 0 & 9 \\
BLOCK & 2335 & 2.39 & 1.94 & 0 & 1 \\
FAMILY & 2335 & .76 & 0.43 & 0 & 13.34 \\
FSIZE & 2335 & 8.43 & 1.7 & 3.86 & 3.74 \\
LEV & 2335 & .36 & 12.3 & -593.03 & 21.42 \\
MB & 2335 & 1.47 & 2.93 & -2.13 & 157 \\
AGE & 2335 & 38.23 & 21.4 & 2 & 214.19 \\
ROA & 2335 & .038 & 4.87 & -54.08 & \\
\hline
\end{tabular}

Table 2. Correlation

\begin{tabular}{|c|c|c|c|c|c|c|c|c|c|c|c|c|}
\hline & SYNCH & CEO & BSIZE & ВCOM & INST & BLOCK & FAMILY & FSIZE & LEV & MB & AGE & ROA \\
\hline SYNCH & 1.00 & & & & & & & & & & & \\
\hline CEO & -0.15 & 1.00 & & & & & & & & & & \\
\hline BSIZE & 0.22 & -0.15 & 1.00 & & & & & & & & & \\
\hline ВСОМ & 0.05 & -0.12 & 0.11 & 1.00 & & & & & & & & \\
\hline INSTOWN & 0.19 & -0.11 & 0.17 & -0.01 & 1.00 & & & & & & & \\
\hline BLOCK & -0.09 & -0.01 & -0.02 & 0.02 & -0.03 & 1.00 & & & & & & \\
\hline FAMILY & -0.20 & 0.11 & -0.33 & -0.05 & -0.21 & 0.12 & 1.00 & & & & & \\
\hline FSIZE & 0.43 & -0.11 & 0.42 & 0.017 & 0.23 & -0.05 & -0.26 & 1.00 & & & & \\
\hline LEV & 0.01 & -0.03 & 0.03 & -0.005 & 0.003 & 0.02 & -0.01 & 0.03 & 1.00 & & & \\
\hline
\end{tabular}




\begin{tabular}{lcccccccccccc}
\hline MB & 0.05 & -0.13 & 0.13 & -0.11 & 0.06 & -0.06 & -0.16 & 0.11 & 0.0082 & 1.00 & \\
AGE & -0.02 & -0.04 & 0.14 & -0.030 & 0.01 & -0.07 & -0.19 & 0.11 & 0.0161 & 0.1617 & 1.00 & \\
ROA & 0.01 & 0.04 & 0.01 & -0.003 & 0.001 & 0.001 & -0.003 & 0.002 & -0.01 & 0.01 & 0.01 & 1.00 \\
\hline
\end{tabular}

Notes: The table reports Pearson pairwise correlation between all variables defined previously.

\subsection{Correlation Analysis}

Table 2 reports the correlation between all variables used in equation 3. CEO, BLOCK, FAMILY, and AGE are negatively correlated with the SYNCH, while BSIZE, BCOM, INSTOWN, FSIZE, LEV, MB and ROA are positively associated with synchronicity. This table also serves as a simple test of multicollinearity among the explanatory variables. It is clear from the table that none of the variables has a high correlation suggesting no signs of multicollinearity among the explanatory variables. In addition to correlation, we also used the Variance Inflation Factor (VIF) as a test of multicollinearity and found similar results.

\subsection{Regression Results}

Table 3 reports the OLS regression results of corporate governance and synchronicity. The results find a negative relationship between CEO duality on firm informativeness. This statistically significant relationship is consistent with the notion when the CEO is also the board chairman; he has the incentive to increase the transparency of the firm (Methew et al., 2015). Our board variables, i.e., board size and board independence, have a positive but insignificant relationship with the synchronicity. This argument of a larger board is associated with less informativeness, which is in line with the Jensen (1993) free-rider effect. Larger boards have less candid discussions on critical issues, which lead to poor monitoring and hence poor informativeness. Moreover, board size and board composition do not contribute positively in Pakistan.

Turning towards ownership, we find a positive relation between institutional ownership and price informativeness. The cause for this positive relationship can result from two reasons. First, sometimes institutional investors enter the equity market only to put their extra cash flows, or they are not actively exercising their monitoring role, which leads to a poor information environment. Second, when the institutional investors own small stakes or focus on short term gains, they have less incentive to involve in the active monitoring of the firm leading to poor information environment (Bogle 2019 and An 2013).

We find a negative relationship between block holders and synchronicity. As discussed earlier, ownership in emerging markets is often in the hands of large blocks having control over decision making (Rehman et al., 2012). These majority controlling shareholders have large incentives to monitor the firm. The active monitoring by the controlling shareholders limits the managers' discretion and extraction of cash flows, which leads to better informativeness. Consistent with these arguments, family firms also have strong monitoring by the family members on the board and management as well; hence there is also an inverse relationship between family ownership and synchronicity.

Table 3: Regression Analysis

\begin{tabular}{cccc}
\hline Dependent Variable: SYNCH & Coefficients & Std. Error & t-statistics \\
\hline CEO & $-.5917^{* * * *}$ & .1204 & -4.91 \\
BSIZE & $(0.000)$ & .0330 & 0.52 \\
BCOM & $(0.603)$ & & .0026 \\
INSTOWN & .0031 & .228 & 1.21 \\
BLOCK & $.9268^{* * *}$ & .2069 & 4.48 \\
FAMILY & $(0.000)$ & .0239 & -3.72 \\
& $-.0889^{* * *}$ & $.0 .000)$ & -4.06 \\
\hline
\end{tabular}




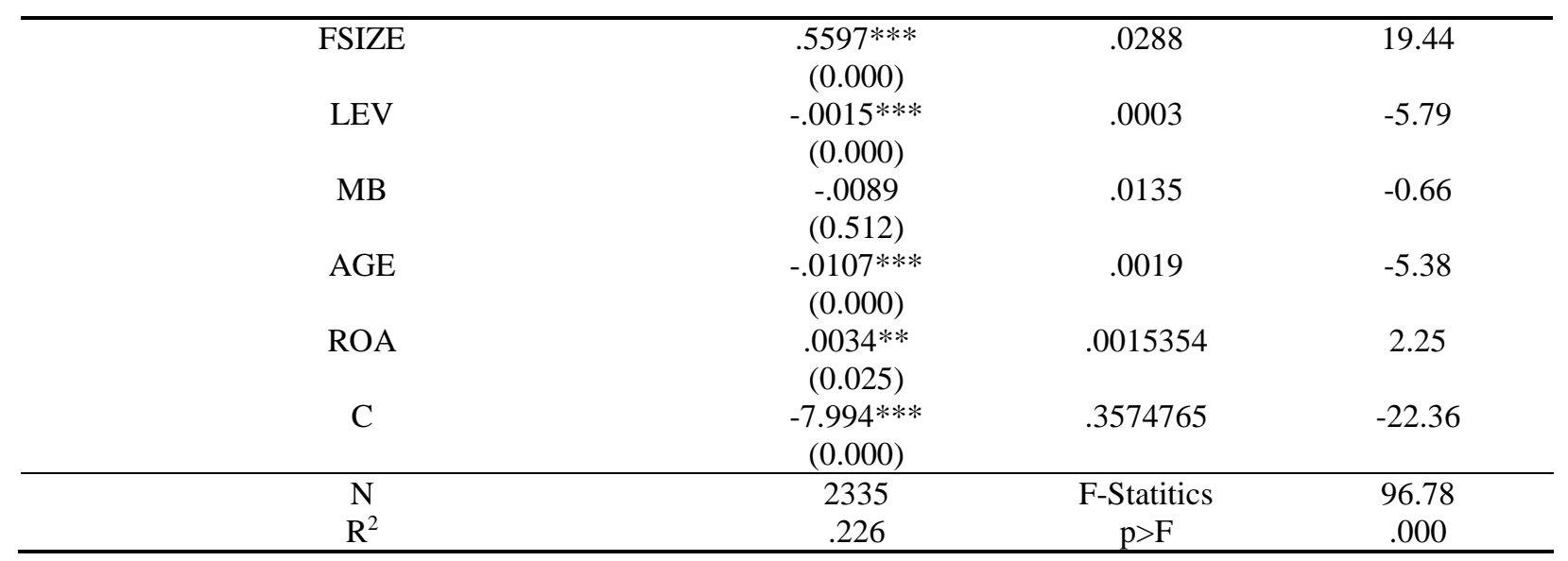

For other control variables, our results are consistent with the previous research of An and Zhang (2013) and Hutton et al. (2009). The firm size shows a positive relationship with synchronicity. The large and profitable firms have diverse operations, thus have higher synchronicity or poor informativeness. Leverage has a negative effect on synchronicity as debt plays an important monitoring role and improves informativeness. Similarly, older firms have better information environment and exhibit lower synchronicity.

We further add industry and year fixed effects in the main regression models and results are reported in Table 4. The results are almost the same as reported earlier, except the market to book ratio (MB) which turned to negative. The findings suggests that firms having a higher market to book ratio and growth potential have more firm-specific informativeness as compared to their counterparts (Hutton et al., 2009).

Table 4: Industry and Year Fixed Effects

\begin{tabular}{|c|c|c|c|}
\hline Dependent Variable: SYNCH & Coefficients. & Std. Error & t-statistics \\
\hline CEO & $\begin{array}{c}-.2903 * * \\
(0.012)\end{array}$ & .1159 & -2.51 \\
\hline BSIZE & $\begin{array}{l}-.0232 \\
(0.456)\end{array}$ & .0312 & -0.75 \\
\hline BCOM & $\begin{array}{c}.0016 \\
(0.504)\end{array}$ & .0024 & 0.67 \\
\hline INSTOWN & $\begin{array}{c}.5135 * * * \\
(0.009)\end{array}$ & .1954 & 2.63 \\
\hline BLOCK & $\begin{array}{c}-.0458 * * \\
(0.043)\end{array}$ & .0226 & -2.02 \\
\hline FAMILY & $\begin{array}{l}-.1013 \\
(0.367)\end{array}$ & .1122 & -0.90 \\
\hline FSIZE & $\begin{array}{c}.4701 * * * \\
(0.000)\end{array}$ & .0297 & 15.83 \\
\hline LEV & $\begin{array}{c}.0002 \\
(0.661)\end{array}$ & .0004 & 0.44 \\
\hline MB & $\begin{array}{c}-.0358 * * \\
(0.012)\end{array}$ & .0143 & -2.51 \\
\hline AGE & $\begin{array}{c}-.0102 * * * \\
(0.000)\end{array}$ & .0020 & -4.96 \\
\hline ROA & $\begin{array}{c}.0071 * * \\
(0.019)\end{array}$ & .0030 & 2.34 \\
\hline $\mathbf{C}$ & $\begin{array}{c}-8.370 * * * \\
(0.000)\end{array}$ & .3747 & -22.33 \\
\hline $\begin{array}{l}\mathbf{N} \\
\mathbf{R}^{2}\end{array}$ & $\begin{array}{c}2335 \\
.349\end{array}$ & $\begin{array}{c}\text { F-Statitics } \\
p>F\end{array}$ & $\begin{array}{c}62.37 \\
.000\end{array}$ \\
\hline
\end{tabular}

Notes: This table reports the results of industry and year fixed effects.

\subsection{Robustness Tests}

The results presented above have not considered potential endogeneity that may exist in corporate governance variables. For the purpose, we employed an instrumental variable approach, namely the two-stage least square 
regression (2SLS). Following (Cao et al., 2018), the study uses the industry average board size as an instrumental variable to precisely estimate synchronicity. We use board size for two reasons; one, board size exhibits variations across twelve different industries used in our sample. The other, it is unlikely that the average industry board size can be correlated with the measure of informativeness. In the first stage regression, we regressed the average industry board size on corporate governance variables. In the second stage regression, the model use predicted board size along with our other variables in the original model. Table 5 presents the 2SLS results using predicted values of board size. Our results largely remain robust to using instrumental variables, except the board size turned significant. We already explained the presence of the free-rider effect might cause the larger board to positively contribute firm synchronicity.

Table 5: Two Stage Least Square (2SLS)

\begin{tabular}{|c|c|c|c|}
\hline Dependent Variable: SYNCH & Coefficients. & Std. Error & t-statistics \\
\hline $\begin{array}{c}\text { BSIZE } \\
\text { (Predicted) }\end{array}$ & $\begin{array}{l}.4075^{*} \\
(0.053)\end{array}$ & .2105 & 1.94 \\
\hline CEO & $\begin{array}{c}-.1938 \\
(0.130)\end{array}$ & .1279 & -1.52 \\
\hline BCOM & $\begin{array}{c}.0001 \\
(0.965)\end{array}$ & .0026 & 0.04 \\
\hline INSTOWN & $\begin{array}{c}.4486 * * \\
(0.036)\end{array}$ & .2144 & 2.09 \\
\hline BLOCK & $\begin{array}{c}-.0649 * * * \\
(0.009)\end{array}$ & .0249 & -2.60 \\
\hline FAMILY & $\begin{array}{c}.0917 \\
(0.546)\end{array}$ & .1517 & 0.60 \\
\hline FSIZE & $\begin{array}{c}.3718 * * * \\
(0.000)\end{array}$ & .0574 & 6.48 \\
\hline LEV & $\begin{array}{l}-.0005 \\
(0.285)\end{array}$ & .0005 & -1.07 \\
\hline MB & $\begin{array}{c}-.0463 * * * \\
(0.003)\end{array}$ & .0158 & -2.93 \\
\hline AGE & $\begin{array}{c}-.0124 * * * \\
(0.000)\end{array}$ & .00245 & -5.05 \\
\hline ROA & $\begin{array}{l}.0065^{* *} \\
(0.029) \\
\end{array}$ & .0029819 & 2.19 \\
\hline $\begin{array}{c}\mathbf{N} \\
\mathbf{R}^{2}\end{array}$ & $\begin{array}{c}2335 \\
.299\end{array}$ & $\begin{array}{c}\text { F-Statitics } \\
p>F\end{array}$ & $\begin{array}{c}59.30 \\
.000\end{array}$ \\
\hline
\end{tabular}

\section{Conclusion}

This paper provides evidence on the relationship between corporate governance and stock price informativeness in a unique setting of an emerging market. Emerging markets are usually characterized by poor governance and information environment. The poor information environment results in higher volatility unrelated to firm fundamentals, higher risk, and lower investment efficiency. We documented how effective corporate governance helps to improve the information environment? We find that controlling shareholders in the form of block holding plays an effective role in improving informativeness. Due to the presence of these block ownership, the institutional investors remain largely short term investors and act passively. This behavior of institutional investors encourages managers to extract more cash flows leading to higher synchronicity. In our case, due to the free-rider effect, board size and composition do not act as monitoring agents and have no role in improving informativeness. These findings suggest market regulators develop such a corporate governance mechanism that not only ensures investor protection but also enjoin firms to reduce information asymmetry by better disclosure and transparency. More specifically, in the Pakistani context, traditional corporate governance mechanisms through board room regulations may not improve informativeness, and regulators need to regulate the ownership regulations, including family ownership and controlling shareholders. Moreover, steps need to be taken to encourage institutional investors to participate actively through maintaining their stakes for longer time periods.

\section{References}

Alves, P., Peasnell, K., \& Taylor, P. (2010). The use of the R2 as a measure of firm-specific information: A crosscountry critique. Journal of Business Finance \& Accounting, 37(1-2), 1-26. 
An, H., \& Zhang, T. (2013). Stock price synchronicity, crash risk, and institutional investors. Journal of Corporate Finance, 21, 1-15.

Arshad, S., Rizvi, S. A. R., Ghani, G. M., \& Duasa, J. (2016). Investigating stock market efficiency: A look at OIC member countries. Research in international business and finance, 36, 402-413.

Balasubramanian, N., Black, B. S., \& Khanna, V. (2010). The relation between firm-level corporate governance and market value: A case study of India. Emerging Markets Review, 11(4), 319-340.

Boubaker, S., Mansali, H., \& Rjiba, H. (2014). Large controlling shareholders and stock price synchronicity. Journal of Banking \& Finance, 40, 80-96.

Brockman, P., \& Yan, X. S. (2009). Block ownership and firm-specific information. Journal of Banking \& Finance, 33(2), 308-316.

Budsaratragoon, P., Hillier, D., \& Lhaopadchan, S. (2014). Does Corporate Governance Improve Transparency in Emerging Markets? Journal of Financial Management, Markets and Institutions, 2(1), 87-104.

Campbell, J. Y., Lettau, M., Malkiel, B. G., \& Xu, Y. (2001). Have individual stocks become more volatile? An empirical exploration of idiosyncratic risk. The Journal of finance, 56(1), 1-43.

Cao, F., Ye, K., Zhang, N., \& Li, S. (2018). Trade credit financing and stock price crash risk. Journal of International Financial Management \& Accounting, 29(1), 30-56.

Chen, J., Chan, K. C., Dong, W., \& Zhang, F. (2017). Internal control and stock price crash risk: Evidence from China. European Accounting Review, 26(1), 125-152.

Chen, Q., Goldstein, I., \& Jiang, W. (2006). Price informativeness and investment sensitivity to stock price. The Review of Financial Studies, 20(3), 619-650.

Dasgupta, S., Gan, J., \& Gao, N. (2010). Transparency, price informativeness, and stock return synchronicity: Theory and evidence. Journal of Financial and Quantitative Analysis, 45(5), 1189-1220.

De Long, J. B., Shleifer, A., Summers, L. H., \& Waldmann, R. J. (1990). Noise trader risk in financial markets. Journal of political Economy, 98(4), 703-738.

DeLisle, R. J., French, D. W., \& Schutte, M. G. (2017). Passive Institutional Ownership, R2 Trends, and Price Informativeness. Financial Review, 52(4), 627-659.

Ding, R., Hou, W., Kuo, J.-M., \& Lee, E. (2017). Regional institutions, financial analysts and stock price informativeness. Regional Studies, 1-10.

Durnev, A., \& Kim, E. H. (2005). To steal or not to steal: Firm attributes, legal environment, and valuation. The Journal of finance, 60(3), 1461-1493.

Fairchild, L., \& Li, J. (2005). Director quality and firm performance. Financial Review, 40(2), 257-279.

Feng, X., Hu, N., \& Johansson, A. C. (2016). Ownership, analyst coverage, and stock synchronicity in China. International Review of Financial Analysis, 45, 79-96.

Fich, E. M., \& Shivdasani, A. (2006). Are busy boards effective monitors? The Journal of finance, 61(2), 689-724.

Gul, F. A., Kim, J.-B., \& Qiu, A. A. (2010). Ownership concentration, foreign shareholding, audit quality, and stock price synchronicity: Evidence from China. journal of financial economics, 95(3), 425-442.

Hasan, I., Song, L., \& Wachtel, P. (2014). Institutional development and stock price synchronicity: Evidence from China. Journal of Comparative Economics, 42(1), 92-108.

Hutton, A. P., Marcus, A. J., \& Tehranian, H. (2009). Opaque financial reports, R2, and crash risk. journal of financial economics, 94(1), 67-86.

Jensen, M. C. (1993). The modern industrial revolution, exit, and the failure of internal control systems. The Journal of finance, 48(3), 831-880.

Jin, L., \& Myers, S. C. (2006). R2 around the world: New theory and new tests. journal of financial economics, 79(2), 257-292.

Jin, Y., Yan, M., Xi, Y., \& Liu, C. (2016). Stock price synchronicity and stock price crash risk: Based on the mediating effect of herding behavior of QFII. China Finance Review International, 6(3), 230-244.

Kim, J. B., \& Zhang, L. (2016). Accounting conservatism and stock price crash risk: Firm-level evidence. Contemporary accounting research, 33(1), 412-441.

Kun, L., Yu, L., \& Hu, X. (2017). The Impact of Institutional Investors on Stock Price Synchronicity: Evidence from the Shanghai Stock Market. Paper presented at the International Conference on Management Science and Engineering Management. 
Love, I., \& Klapper, L. F. (2002). Corporate governance, investor protection, and performance in emerging markets: The World Bank.

Luo, M., Chen, T., \& Yan, I. K. (2014). Price informativeness and institutional ownership: evidence from Japan. Review of Quantitative Finance and Accounting, 42(4), 627-651.

Morck, R., Yeung, B., \& Yu, W. (2000). The information content of stock markets: why do emerging markets have synchronous stock price movements? journal of financial economics, 58(1-2), 215-260.

Piotroski, J. D., \& Roulstone, D. T. (2004). The influence of analysts, institutional investors, and insiders on the incorporation of market, industry, and firm-specific information into stock prices. The Accounting Review, 79(4), 1119-1151.

Rehman, R., Hasan, M., Mangla, I. U., \& Sultana, N. (2012). Economic reforms, corporate governance and dividend policy in sectoral economic growth in Pakistan. The Pakistan Development Review, 133-145.

Roll, R. (1988). R2. The Journal of finance, 43(3), 541-566. doi: doi:10.1111/j.1540-6261.1988.tb04591.x

Sheikh, M. F., Shah, S. Z. A., \& Akbar, S. (2018). Firm performance, corporate governance and executive compensation in Pakistan. Applied economics, 50(18), 2012-2027.

Shleifer, A., \& Vishny, R. W. (1987). Management buyouts as a response to market pressure Mergers and acquisitions (pp. 87-102): University of Chicago Press.

Ye, K., Guan, J. X., \& Zhang, B. (2018). Strategic Deviation and Stock Return Synchronicity. Journal of Accounting, Auditing \& Finance, $0148558 \mathrm{X} 18802551$.

Yeung, W. H., \& Lento, C. (2018). Ownership structure, audit quality, board structure, and stock price crash risk: Evidence from China. Global Finance Journal, 37, 1-24. 


\section{Appendix 1: Sampling Firms}

\section{a) Sector-wise distribution of sample firms}

b) All Companies Included in Sample

\begin{tabular}{|c|c|c|c|c|c|}
\hline Industr & Company Name & Industr & Company & Indust & Company Name \\
\hline 1 & Ahmed Hassan & 2 & Ansari Sugar & 5 & Bestway \\
\hline
\end{tabular}

\begin{tabular}{|c|c|c|c|c|c|}
\hline Industry & \multicolumn{3}{|l|}{ Industry Name } & \multicolumn{2}{|c|}{ Number of Firms } \\
\hline 1 & \multicolumn{3}{|l|}{ Textile } & \multicolumn{2}{|c|}{85} \\
\hline 2 & \multicolumn{3}{|l|}{ Food } & \multicolumn{2}{|c|}{36} \\
\hline 3 & \multicolumn{3}{|c|}{ Chemicals, Chemical Products \& Pharma } & \multicolumn{2}{|c|}{37} \\
\hline 4 & \multicolumn{3}{|c|}{ Other Manufacturing } & \multicolumn{2}{|c|}{17} \\
\hline 5 & \multicolumn{3}{|c|}{ Other Non-Metallic Mineral Products - Overall } & \multicolumn{2}{|c|}{22} \\
\hline 6 & \multicolumn{3}{|c|}{ Motor Vehicles, Trailers and Auto parts } & \multicolumn{2}{|c|}{18} \\
\hline 7 & \multicolumn{3}{|c|}{ Fuel \& Energy } & \multicolumn{2}{|c|}{14} \\
\hline 8 & \multicolumn{3}{|c|}{ Information, Comm. and Transport Services } & \multicolumn{2}{|c|}{10} \\
\hline 9 & \multicolumn{3}{|c|}{ Coke \& Refined Petroleum Products } & \multicolumn{2}{|c|}{9} \\
\hline 10 & \multicolumn{3}{|c|}{ Paper, Paperboard and Products } & \multicolumn{2}{|l|}{6} \\
\hline 11 & \multicolumn{3}{|c|}{ Electrical Machinery and Apparatus } & \multicolumn{2}{|l|}{5} \\
\hline 12 & \multicolumn{3}{|c|}{ Other Services Activities } & \multicolumn{2}{|l|}{5} \\
\hline & Total & & & 26 & \\
\hline 1 & Ali Asghar Textile & 2 & Baba $\quad$ Farid & 5 & Cherat Cement Co. \\
\hline 1 & Allawasaya Textile & 2 & Chashma & 5 & D.G. Khan Cement \\
\hline 1 & Artistic Denim Mills & 2 & Colony Sugar & 5 & Dandot Cement Co. \\
\hline 1 & Ashfaq Textile Mills & 2 & Dewan Sugar & 5 & Dewan Cement Ltd. \\
\hline 1 & Asim Textile Mills & 2 & Faran Sugar & 5 & Fauji Cement Co. \\
\hline 1 & Azgard Nine Ltd. & 2 & Habib Sugar & 5 & Fecto Cement Ltd. \\
\hline 1 & Babri Cotton Mills & 2 & Haseeb & 5 & Flying Cement Ltd. \\
\hline 1 & Bhanero $\quad$ Textile & 2 & Husein Sugar & 5 & Gharibwal Cement \\
\hline 1 & Bilal Fibres Ltd. & 2 & JDW Sugar & 5 & Kohat Cement Co. \\
\hline 1 & Blessed $\quad$ Textiles & 2 & Mehran & 5 & Lucky Cement Ltd. \\
\hline 1 & Chakwal Spinning & 2 & Mirpurkhas & 5 & Maple Leaf Cement \\
\hline 1 & Colony Mills Ltd. & 2 & Mirza Sugar & 5 & Pioneer Cement Ltd. \\
\hline 1 & Crescent Fibers Ltd. & 2 & Noon Sugar & 5 & Thatta Cement Ltd. \\
\hline 1 & D.M. Textile Mills & 2 & Sakrand & 5 & Balochistan $\quad$ Glass \\
\hline 1 & D.S. Industries Ltd. & 2 & Sanghar & 5 & Ghani Glass Ltd. \\
\hline 1 & Dawood & 2 & Shahmurad & 5 & Ghani Value Glass \\
\hline 1 & Farooque & 2 & Shahtaj Sugar & 5 & Karam Ceramics Ltd. \\
\hline 1 & Dewan & 2 & Shakarganj & 5 & Safe Mix Concrete \\
\hline 1 & Dewan Mushtaq & 2 & The Premier & 5 & Shabbir Tiles And \\
\hline 1 & Dewan Textile Mills & 2 & The Thal & 5 & Tariq Glass \\
\hline 1 & $\begin{array}{lll}\text { Din } & \text { Textile } & \text { Mills } \\
\end{array}$ & 2 & Clover & 6 & Agriauto \\
\hline 1 & Elahi Cotton Mills & 2 & Ismail & 6 & Al-Ghazi $\quad$ Tractors \\
\hline 1 & Ellcot $\quad$ Spinning & 2 & Mitchell'S & 6 & Atlas Battery Ltd. \\
\hline 1 & Faisal Spinning & 2 & Murree & 6 & Atlas Honda Ltd. \\
\hline 1 & Fazal Cloth Mills & 2 & National & 6 & Baluchistan Wheels \\
\hline 1 & $\begin{array}{ll}\text { Feroze1888 } & \text { Mills } \\
\end{array}$ & 2 & Nestle & 6 & Bolan Castings Ltd. \\
\hline 1 & Gadoon & 2 & Noon & 6 & Dewan Farooque \\
\hline
\end{tabular}




\begin{tabular}{|c|c|c|c|c|c|}
\hline 1 & Hafiz Textile Mills & 2 & Punjab Oil & 6 & Exide Pakistan Ltd. \\
\hline 1 & Haji $\quad$ Mohammad & 2 & Quice Food & 6 & $\begin{array}{lll}\text { General } & \text { Tyre } \&\end{array}$ \\
\hline 1 & Enterprises & 2 & Rafhan & 6 & Ghandhara Industries \\
\hline 1 & Hira Textile Mills & 2 & Shezan & 6 & Ghandhara Nissan \\
\hline 1 & ICC Textiles Ltd. & 2 & Unilever & 6 & Ghani $\quad$ Automobiles \\
\hline 1 & Idrees Textile Mills & 3 & Abbott & 6 & Hinopak Motors Ltd. \\
\hline 1 & Island Textile Mills & 3 & Agritech Ltd. & 6 & Honda Atlas Cars \\
\hline 1 & $\begin{array}{lll}\text { J.A. } & \text { Textile } & \text { Mills }\end{array}$ & 3 & Bawany Air & 6 & Indus Motor Co. Ltd. \\
\hline 1 & J.K. Spinning Mills & 3 & Berger Paints & 6 & Millat Tractors Ltd. \\
\hline 1 & Janana De Malucho & 3 & Biafo & 6 & $\begin{array}{lll}\text { Pak } & \text { Suzuki } & \text { Motor }\end{array}$ \\
\hline 1 & Jubilee Spinning \& & 3 & Buxly Paints & 6 & Sazgar $\quad$ Engineering \\
\hline 1 & Khalid Siraj Textile & 3 & Colgate- & 7 & Altern Energy Ltd. \\
\hline 1 & Kohat Textile Mills & 3 & Data Agro & 7 & Burshane LPG \\
\hline 1 & Kohinoor Mills Ltd. & 3 & Dawood & 7 & Japan \\
\hline 1 & Kohinoor Spinning & 3 & Descon & 7 & Karachi \\
\hline 1 & Kohinoor Textile & 3 & Descon & 7 & Kohinoor $\quad$ Energy \\
\hline 1 & Landmark Spinning & 3 & Dewan & 7 & Mari Gas Co. Ltd. \\
\hline 1 & Mahmood Textile & 3 & Dynea & 7 & Nishat Chunian \\
\hline 1 & Maqbool $\quad$ Textile & 3 & Engro & 7 & Nishat Power Ltd. \\
\hline 1 & Masood & 3 & Engro & 7 & Oil $\quad \& \quad$ Gas \\
\hline 1 & Textile & 3 & Fatima & 7 & Sitara Energy Ltd. \\
\hline 1 & Nadeem & 3 & Fauji & 7 & Southern Electric \\
\hline 1 & Nagina Cotton Mills & 3 & Fauji & 7 & Sui $\quad$ Northern Gas \\
\hline 1 & Nishat (Chunian) & 3 & Ghani Gases & 7 & Sui Southern Gas Co. \\
\hline 1 & Nishat Mills Ltd. & 3 & GlaxoSmithK & 7 & The Hub Power Co. \\
\hline 1 & Olympia Spinning \& & 3 & Highnoon & 8 & HUM Network Ltd. \\
\hline 1 & Prosperity Weaving & 3 & ICI Pakistan & 8 & Media Times Ltd. \\
\hline 1 & Quetta Textile Mills & 3 & Ittehad & 8 & Pak Datacom Ltd. \\
\hline 1 & Ravi Textile Mills & 3 & Leiner & 8 & Pakistan Int. \\
\hline 1 & Redco Textiles Ltd. & 3 & Linde & 8 & Pakistan \\
\hline 1 & Reliance $\quad$ Cotton & 3 & Lotte & 8 & Pakistan \\
\hline 1 & Reliance Weaving & 3 & Nimir & 8 & Pakistan \\
\hline 1 & Saif Textile Mills & 3 & Pakistan & 8 & TRG Pakistan Ltd. \\
\hline 1 & Sajjad Textile Mills & 3 & Pakistan PVC & 8 & Telecard Ltd. \\
\hline 1 & $\begin{array}{lll}\text { Salfi } & \text { Textile } & \text { Mills }\end{array}$ & 3 & Sanofi & 8 & $\begin{array}{ll}\text { Worldcall } & \text { Telecom }\end{array}$ \\
\hline 1 & Sally Textile Mills & 3 & Sardar & 9 & Attock $\quad$ Petroleum \\
\hline 1 & Salman Noman & 3 & Searle & 9 & Attock Refinery Ltd. \\
\hline 1 & Samin Textiles Ltd. & 3 & Shaffi & 9 & $\begin{array}{ll}\text { Byco } & \text { Petroleum }\end{array}$ \\
\hline 1 & Sana Industries Ltd. & 3 & Sitara & 9 & National \\
\hline 1 & Sapphire Fibres Ltd. & 3 & Sitara & 9 & Pakistan \\
\hline 1 & Sapphire $\quad$ Textile & 3 & Wah Nobel & 9 & Petroleum \\
\hline 1 & Sargodha Spinning & 3 & Wyeth & 9 & Pakistan $\quad$ Refinery \\
\hline 1 & Service Industries & 4 & Bata Pakistan & 9 & Pakistan State Oil \\
\hline 1 & Shadab Textile Mills & 4 & Crescent & 9 & Shell Pakistan Ltd. \\
\hline 1 & Shahtaj Textile Ltd. & 4 & Dadex Eternit & 10 & Century Paper \& \\
\hline 1 & Shahzad Textile & 4 & Dost $\quad$ Steels & 10 & Cherat Packaging \\
\hline 1 & Shams Textile Mills & 4 & Pack & 10 & Merit Packaging Ltd. \\
\hline 1 & Sunrays $\quad$ Textile & 4 & Emco & 10 & Packages Ltd. \\
\hline 1 & Suraj Cotton Mills & 4 & Gillette & 10 & Pakistan Paper \\
\hline 1 & Tata Textile Mills & 4 & Huffaz & 10 & Security Papers Ltd. \\
\hline
\end{tabular}




\begin{tabular}{|l|l|l|l|l|l|}
\hline 1 & The Crescent Textile & 4 & KSB Pumps & 11 & Ados Pakistan Ltd. \\
\hline 1 & Zephyr Textiles Ltd. & 4 & Pakistan & 11 & Pak Elektron Ltd. \\
\hline 1 & Gul Ahmed Textile & 4 & Philip Morris & 11 & Pakistan Cables Ltd. \\
\hline 1 & Al-Abid Silk Mills & 4 & Service & 11 & Siemens (Pakistan) \\
\hline 1 & Bannu Woollen & 4 & Siddiqsons & 11 & Singer Pakistan Ltd. \\
\hline 1 & Crescent Jute & 4 & Treet & 12 & IBL HealthCare Ltd. \\
\hline 1 & Ibrahim Fibres Ltd. & 4 & Tri-Pack & 12 & Javedan Corporation \\
\hline 2 & Adam Sugar Mills & 4 & United & 12 & Pace (Pakistan) Ltd. \\
\hline 2 & Al-Abbas Sugar & 4 & ZIL Ltd. & 12 & Pakistan Services \\
\hline 2 & Al-Noor Sugar Mills & 5 & Attock & 12 & Shifa International \\
\hline
\end{tabular}

